\section{Salicylic acid-induced glutathione status in tomato crop and resistance to root-knot nematode, Meloidogyne incognita (Kofoid \& White) Chitwood}

\author{
Hari C. Meher, Vijay T. Gajbhiye, \\ Ghanendra Singh \\ Indian Agricultural Research Institute, \\ New Delhi, India
}

\section{Abstract}

Salicylic acid-(SA) is a plant defense stimulator. Exogenous application of SA might influence the status of glutathione-(GSH). GSH activates and SA alters the expression of defense genes to modulate plant resistance against pathogens. The fate of GSH in a crop following SA treatment is largely unknown. The SA-induced profiles of free reduced-, free oxidized-(GSSG) and protein bound-(PSSG) glutathione in tomato crop following foliar treatment of transplant at $5.0-10.0 \mu \mathrm{g} \mathrm{mL}$ were measured by liquid chromatography. Resistance to root-knot nematode, Meloidogyne incognita damaging tomato and crop performance were also evaluated. SA treatment at 5.0-10.0 $\mu \mathrm{g} \mathrm{mL} \mathrm{m}^{-1}$ to tomato transplants increased GSH, GSSG and PSSG in plant leaf and root, more so in leaf, during crop growth and development. As the fruits ripened, GSH and PSSG increased and GSSG declined. SA reduced the root infection by $M$. incognita, nematode reproduction and thus, improved the resistance of tomato var. Pusa Ruby, but reduced crop growth and redox status. SA at $5.0 \mu \mathrm{g} \mathrm{mL} \mathrm{mL}^{-1}$ improved yield and fruit quality. The study firstly linked SA with activation of glutathione metabolism and provided an additional dimension to the mechanism of induced resistance against obligate nematode pathogen. SA increased glutathione status in tomato crop, imparted resistance against $M$. incognita, augmented crop yield and functional food quality. SA can be applied at $5.0 \mu \mathrm{g} \mathrm{mL}^{-1}$ for metabolic engineering of tomato at transplanting to combine host-plant resistance and health benefits in formulating a strategic nematode management decision.

\section{Introduction}

Glutathione (L- $\gamma$-glutamyl-L-cysteinylglycine) (GSH) is a tripeptide synthesized from glutamate, cysteine and glycine by the enzyme $\gamma$-glutamylcysteine synthetase (GSH1) and GSH synthetase (GSH2) in two adenosine triphosphate (ATP) dependent reactions. ${ }^{1}$ GSH being a key regulator of redox signaling and buffering activates defense genes. ${ }^{2}$ SA linked with systemic acquired resistance (SAR) of plants to pathogens $^{3-6}$ alters expression of defense genes. ${ }^{7}$ The redox signaling is interlinked with the network of phytohormones. ${ }^{8,9}$ The involvement of GSH in cellular metabolism and its potential agro-biotechnological application has been realized to resist biotic and abiotic stress and pests and in recent years, up regulation of GSH considered to enhance pathogen resistance in plant models or crops. ${ }^{10,11}$ Very little information is available regarding the fate of GSH in crop following exogenous SA application. ${ }^{12}$ The real question is what happens to GSH when SA is applied and is this related to a decrease in pathogen infection and a subsequent increase in yield/plant quality. GSH is also considered a nutrient ${ }^{13}$ because dietary GSH and its precursors enhance tissue levels of GSH in humans and prevent or reduce the risk of malignancy, ${ }^{14,15}$ idiopathic pulmonary fibrosis, ${ }^{16}$ adult respiratory distress syndrome ${ }^{17}$ and human immunodeficiency virus-related disease ${ }^{18}$ Combining host plant resistance to pests with healthy food characters is a promising future prospect. Tomato (Solanum lycopersicum $L$.), being a high-value horticultural fruit crop, was chosen for this study. The crop suffers 22 $70 \%$ yield loss in tropical and subtropical regions due to root-knot nematode, Meloidogyne incognita (Kofoid \& White) Chitwood. ${ }^{19}$ Nematode-resistant tomatoes are lacking except for a few varieties and therefore grower demand is not met. A better understanding of GSH metabolism would be a key to impart crop resistance by exogenous application of SA and gain more effective control of GSH level in food. Therefore, the present study was undertaken to estimate free reduced glutathione (GHS), free oxidized glutathione (GSSG) and protein bound glutathione (PSSG) in root, shoot and fruit of a susceptible tomato crop cultivar Pusa Ruby, at regular predetermined intervals, following spray application of SA and to evaluate crop performance and resistance to root-knot nematode $M$. incognita, as also assess fruit quality and indirectly assign enzyme functions.

\section{Materials and Methods}

\section{Analytical standards, reagents and solvents}

Deionized water was used throughout the work. All chemicals were analytical grade. Bathophenanthroline disulfonic acid (BPDS), m-cresol, oxidized glutathione (GSSG), reduced glutathione (GSH), iodoacetic acid
Correspondence: Hari C. Meher, Indian Agricultural research Institute, New Delhi 110012, India.

Tel. +91.9891994474 - Fax: +91.11.25843272.

E-mail: hcm_nema@yahoo.com

Key words: glutathione, salicylic acid, Solanum lycopersicum, Meloidogyne incognita, resistance, yield.

Acknowledgments: the authors would like to thank the Director, Indian Agricultural Research Institute for providing facilities and Dr. K.K. Kaushal, Division of Nematology and K.C. Bansal, National Research Centre for Plant Biotechnology, Indian Agricultural Research Institute, for their constructive contributions.

Contributions: HCM, manuscript conception, design, interpretation and preparation; VTG, manuscript interpretation and revision; GS, data analysis and field experiment conduction.

Received for publication: 17 May 2011.

Accepted for publication: 29 September 2011.

This work is licensed under a Creative Commons Attribution NonCommercial 3.0 License (CC BYNC 3.0).

(C)Copyright H.C. Meher et al., 2011

Licensee PAGEPress, Italy

Journal of Xenobiotics 2011; 1:e5

doi:10.4081/xeno.2011.e5

(IAA), hydrochloric acid, perchloric acid (PCA) and 1-fluoro-2, 4- dinitrobenzene (DNFB) were obtained from Sigma Chemical Co. (St. Louis, M0, U.S.A). Dithiothreitol (DTT), potassium hydroxide $(\mathrm{KOH})$, potassium bicarbonate $\left(\mathrm{KHCO}_{3}\right)$, and trifluoro acetic acid (TFA) were from Merck, GmbH, Germany. All solvents used were of HPLC grade and procured from Sisco Research Laboratories Pvt. Ltd., India.

\section{Field experiment}

A field experiment was conducted at the Indian Agricultural Research Institute, New Delhi, in a randomized block design in field micro plots of $8 \mathrm{~m}^{2}$ sizes, with 3 rates of salicylic acid (SA) treatments and 5 replications. The plots were naturally infested with $M$. incognita besides other ectoparasitic nematodes. A single application of recommended fertilizer (25:50:25 NPK kg/ha) was applied a day before transplanting tomato $S$. lycopersicum (L.). Thirty-five-day-old seedlings of tomato cv Pusa Ruby were sprayed on the foliage (1 mL/seedling) with SA at 0.0, 5.0 and $10.0 \mu \mathrm{g} / \mathrm{mL}^{-1}$ and transplanted to soil plots at inter- and intra row spacings of 50 and $30 \mathrm{~cm}$, respectively. The plots were flood irrigated ( 5 $\mathrm{cm}$ ) at intervals of 20 days. The weeds from the plots were subsequently removed manually. 


\section{Evaluation of crop performance}

Plant resistance to $M$. incognita was assessed in terms of root-knot index and soil population of $M$. incognita. Root-knot index was estimated on the $120^{\text {th }}$ day. ${ }^{20}$ Nematode population in soil was estimated on 0 and 120 days after transplanting of tomato. For this, soil samples were taken from the plow layer (15 cm deep) by a soil-sampling auger (45 X $2.5 \mathrm{~cm}$ ) representing approximately 25 cores from each treatment. An aliquot of $200 \mathrm{~cm}^{3}$ soils was processed by standard Cobb's modified decanting and sieving techniques. The shoot length was measured on $120^{\text {th }}$ day. Yield data were pooled from all the harvests of each plot and expressed as tons/ha.

\section{Evaluation of glutathione status in tomato}

The changes in glutathione status in tomato plants were evaluated by analyzing free and bound glutathione in different plant parts. Root and leaf samples (1-3 g fresh weight) were taken after $0,15,30,60,90$ and 120 days and fruit samples after 90,110, and 130 days of treatments. The samples were processed for analysis by liquid chromatography (LC).

\section{Sample preparation for liquid Chromatography Extraction}

Samples of root, leaf and fruit were extracted separately in $20 \mathrm{~mL}$ of extraction solvent methanol: water (2:1) containing $3 \%$ perchloric acid (PCA), $0.1 \%$ trifluoro acetic acid (TFA) and $0.2 \mathrm{mM}$ bathophenanthroline disulfonic acid (BPDS) and centrifuged for extraction of free GSH and GSSG by the procedure adopted for analysis of amino and organic acids. ${ }^{21}$ The extracts were saturated with nitrogen and stored at $-20^{\circ} \mathrm{C}$ till analysis. An aliquot of $1.5 \mathrm{~mL}$ was concentrated to $500 \mu \mathrm{L}$ in a Labconco (Kansas City, M0, USA) Centrivap vacuum concentrator at $35^{\circ} \mathrm{C}$. For extraction of glutathione from PCA insoluble glutathionylated (PSSG) proteins, the pellet was extracted overnight with $800-1000 \mu \mathrm{L}$ of $2.4 \mathrm{M} \mathrm{KHCO} 3(\mathrm{pH} 8.1) / 0.025 \mathrm{M}$ dithiothreitol by shaking at $200 \mathrm{rpm}$ in a Kuhner (Basel, Switzerland) Labtherm incubator shaker, centrifuged at $4000 \mathrm{rpm}$ for $30 \mathrm{~min}$ at $4^{\circ} \mathrm{C}$ in a Heraeus Biofuge 22R centrifuge (Osterode, Germany) and the supernatant transferred to 1.5 $\mathrm{mL}$ microcentrifuge tube. The pellet was washed with 200 and $100 \mu \mathrm{L}$ portions of $2.4 \mathrm{M} \mathrm{KHCO}_{3}$ and centrifuged. All the supernatants were combined, concentrated to $100-200 \mu \mathrm{L}$ in vacuum concentrator at $35^{\circ} \mathrm{C}$, re-precipitated by adding $300 \mu \mathrm{L}$ of $10 \%$ ice cold PCA and centrifuged at $14,000 \mathrm{rpm}$ for $30 \mathrm{~min}$ at $4^{\circ} \mathrm{C}$ with two washings of $100 \mu \mathrm{L} \mathrm{10 \%} \mathrm{PCA} \mathrm{to} \mathrm{release} \mathrm{protein} \mathrm{bound} \mathrm{glu-}$ tathione. From this $500 \mu \mathrm{L}$ of the extract, an aliquot of $300 \mu \mathrm{L}$ was concentrated to $150 \mu \mathrm{L}$ in a Centrivap vacuum concentrator at $35^{\circ} \mathrm{C}$.

\section{Clean up}

Sample aliquots of $500 \mu \mathrm{L}$ for free GSH and GSSG and $150 \mu \mathrm{L}$ for PSSG, were passed through sample clarification kit (HP part No. 5061-3365) for clean up.

\section{Carboxymethylation}

Carboxymethylation was performed to prevent thiol oxidation. To $100 \mu \mathrm{L}$ of the cleaned extract taken in $1.5 \mathrm{~mL}$ microcentrifuge tube, was added $25 \mu \mathrm{L}$ iodoacetic acid $(100 \mathrm{mM})$ and $200 \mu \mathrm{L} \mathrm{KHCO}{ }_{3}(2.4 \mathrm{M}, \mathrm{pH}$ 8.1). The contents were shaken in dark for $1 \mathrm{~h}$ at $40^{\circ} \mathrm{C}$ and $50 \mathrm{rpm}$ in a Kuhner incubator shaker and then allowed to cool to room temperature.

\section{Derivatization}

Hundred $\mu \mathrm{L}$ of $25 \%$ DNFB in methanol was added to microcentrifuge tube. The tubes were incubated in dark at $40^{\circ} \mathrm{C}$ and $50 \mathrm{rpm}$ for $4 \mathrm{~h}$ in an incubator shaker. Thereafter, the temperature was raised to $80^{\circ} \mathrm{C}$ for $45 \mathrm{~min}$ to remove traces of methanol. The tubes were then left at $40^{\circ} \mathrm{C}$ for another $45 \mathrm{~min}$, allowed to cool and kept in refrigerator. The next day, the tubes were taken out; allowed to cool to room temperature and then $100 \mu \mathrm{L} 6 \mathrm{~N} \mathrm{HCl}$ was added. The residues were extracted thrice with peroxide free cold ether, using 600,400 and $200 \mu \mathrm{L}$ each time. To the combined extract, $100 \mu \mathrm{L}$ acetonitrile was added and ether evaporated in a shaker at $30^{\circ} \mathrm{C}$ and $50 \mathrm{rpm}$.

\section{Liquid chromatography}

\section{LC apparatus}

A binary gradient high pressure liquid chromatograph series 1100 (Agilent Technologies, Palo Alto, CA, USA) equipped with Rheodyne manual injector with a $20 \mu \mathrm{L}$ loop, UV-visible variable wave length detector, $4.6 \times 200 \mathrm{~mm}$ Lichrosorb $5 \mu \mathrm{m}$ NH2 column and a LC 2D chemstation was used for the analysis.

\section{Chromatographic conditions}

The analysis was performed using a mobile phase comprising of A [water + trifluoroacetic acid - (TFA 0.1\%)] and B [acetonitrile + TFA $(0.085 \%)]$. The detector was set at $\lambda$-max of $356 \mathrm{~nm}$. The LC gradient was programmed for 0 to $100 \%$ B in $20 \mathrm{~min}$, held for $5 \mathrm{~min}$, returned to 0 in $5 \mathrm{~min}$ and re-equilibrated for $5 \mathrm{~min}$. The total run time of the method including re-equilibrium was $\sim 35 \mathrm{~min}$.

Fifty $\mu \mathrm{L}$ of the final extract in acetonitrile was injected in to Rheodyne manual injector $(20 \mu \mathrm{L})$. Twenty $\mu \mathrm{L}$ sample was resolved on the chromatographic bed. The reproducibility of the chromatographic method was evaluated by injections of standard solutions on the same day (intra-day) and on various days (inter-day) at monthly intervals over a five-month period.

\section{Peak identification and quantification}

Peak identification for GSH and GSSG in the sample was done by 2 methods: i) comparing their retention times with those of standards and ii) by spiking the standards to the sample. Quantification of the test metabolites was accomplished by comparing integrated chromatographic peak areas from the test samples to the peak areas of known amounts of standards of the metabolite mixtures using LC 2D chemstation software. GSH and GSSG were quantified via external calibration curves based on 4 dilutions of the analytical standard (5-40 $\left.\mu \mathrm{g} \mathrm{mL}^{-1}\right)$.

\section{Recovery and matrix effect}

For recovery analysis and quantification of GSH and GSSG in unknown samples, two types of plant matrices were chosen. A sample of $3 \mathrm{~g}$ of ground tissues of root, shoot and fruits of chickpea Cicer arietinum (L.) and tomato $S$. lycopersicum (L.) were fortified at 1.0 and 10.0 $\mu \mathrm{g} \mathrm{g}^{-1}$ levels and extracted separately at ambient temperature with extraction solvent and the efficiency of the extraction was determined along with cleanup protocols to observe the matrix effect, if any. Unfortified samples served as blank. The amount recovered was calculated from the difference in the amount in fortified sample and blank (natural abundance). The recovery was calculated as the amount recovered $\div$ amount added $X 100$. The precision of the method was obtained by analyzing fortified samples five times.

\section{Statistics}

Multiple correlation regression and multivariate analysis of variance (MANOVA) were accomplished by Statistical Package for Social Sciences (SPSS) for data analysis and interpretation.

\section{Results}

\section{Method validation}

The various parameters for carboxymethylation, nitrophenylation and release of proteinbound glutathione such as temperature, time, volume, buffer, $\mathrm{pH}$ and reagent strength, were optimized. The conditions that worked best as described in the Materials and Method section were utilized for the analysis of GSH and GSSG from root, leaf and fruit tissues of tomato. The mobile phase and the gradient used in the present study could resolve $20 \mu \mathrm{L}$ sample of GSH and GSSG in $<10$ min without any interference due to impurities. The approximate retention time (min) of GSH was 4.7 and GSSG 5.1. The limits of quantification (LOQ) and detection (LOD) of GSH were $50 \mathrm{ng} \mathrm{g}^{-1}$ and $20 \mathrm{ng} \mathrm{mL}^{-1}$ and of GSSG $60 \mathrm{ng} \mathrm{g}^{-1}$ and $20 \mathrm{ng} \mathrm{mL}^{-1}$, respectively. The relative standard deviations (RSDs) of the response factors of peaks of the analytes varied from 2.1 to 
$6.2 \%$, and the migration time from 1.4 to $2.2 \%$ exhibiting a good precision of the method. The peaks identified for root, leaf and fruits samples of chickpea and tomato were the same indicating robustness of the method. Method recoveries of GSH and GSSG at 1.0 and $10.0 \mu \mathrm{g} \mathrm{g}^{-1}$ levels of fortifications of chickpea and tomato tissues varied from 83 to $98 \%$ with RSDs 3.7 to $8.9 \%$. The concentrations of GSH and GSSG have been reported on the basis of $\mu \mathrm{g} \mathrm{g}^{-1}$ fresh weight.

\section{Effect of SA on GSH and GSSG levels in leaf and root}

The data recorded at predetermined inervals revealed that the levels of both GSH and GSSG were more in leaf than root with always a higher concentration of GSH than GSSG (Figure 1).

In the leaves, the concentrations ( $\left.\mu \mathrm{g} \mathrm{g}^{-1}\right)$ of GSH (2.71) and GSSG (0.57) reached maximum levels within 15 days of treatment. In check, the levels declined thereafter except a slight increase by 90 days at the time of anthesis. Application of salicylic acid (SA) increased $(\mathrm{P}<0.05)$ the leaf GSH and GSSG, more so with dosage $(\mathrm{P}<0.05)$ during the entire cropping season (Table 1). Initially, at 0 day ( $6 \mathrm{~h}$ after treatment) the GSH level did not change but that of GSSG increased (Figure 1). Within 15 days, the leaf content of GSH $\left(4.39 \mu \mathrm{g} \mathrm{g}^{-1}\right)$ and of GSSG (1.08 $\left.\mu \mathrm{g} \mathrm{g} \mathrm{g}^{-1}\right)$ was found to almost double in treated plants. The levels decreased by 30 days and increased thereafter up to 90 days. This was followed by a gradual decline of GSH and a sudden reduction of GSSG levels by 120 days. As compared to check, always a higher concentration $(\mathrm{P}<0.05)$ of GSH and GSSG in leaf of treated plants was observed from 0 to 120 days.

In root, the concentration of GSH decreased and that of GSSG remained the same within 6 $h$ after application of SA. The root contents of GSH were found to increase $(\mathrm{P}<0.05)$ intermittently from 15 to 120 days due to basipetal translocation from shoot to root. The maximum root concentrations ( $\left.\mu \mathrm{g} \mathrm{g}^{-1}\right)$ of GSH $(0.17$ in check and 0.21 in plants receiving SA treatment at $10.0 \mu \mathrm{g} \mathrm{mL}^{-1}$ ) were achieved in $30^{\text {th }}$ days. The GSSG level in root (0.085-0.096 $\mu \mathrm{g}$ $\mathrm{g}^{-1}$ ) was highest at transplanting. The level declined up to 120 days except an increase by 90 days at the time of anthesis. However, the concentration of GSSG was more $(\mathrm{P}<0.05)$ in treated than control plants from day $15^{\text {th }}$ onward and was greater $(\mathrm{P}<0.05)$ at higher rate of application $\left(10.0 \mu \mathrm{g} \mathrm{mL}^{-1}\right)$ up to 90 days.

\section{Effect of SA on PSSG levels in leaf} and root

The protein bound glutathione (PSSG) in leaf peaked by 15 days in check $\left(6.75 \mu \mathrm{g} \mathrm{g}^{-1}\right)$ and 30 days in treated $\left(9.86-13.91 \mu \mathrm{g} \mathrm{g}^{-1}\right)$ plants (Figure 1). Always a higher $(\mathrm{P}<0.05)$ concentration of PSSG was observed in treated as compared to check plants except an initial decline after treatment (Table 1). In roots, the levels of PSSG were very low. Maximum concentration of PSSG in root was observed by 90 days in check $\left(0.11 \mu \mathrm{g} \mathrm{g} \mathrm{g}^{-1}\right)$ and 60 days in treated plants $\left(0.12-0.14 \mu g \mathrm{~g}^{-1}\right)$. The root PSSG concentration increased with dosage $(\mathrm{P}<0.05)$ and remained high $(\mathrm{P}<0.05)$ in treated plants throughout the period of crop growth. The data suggested an increase of glutathionylated protein more in leaves than roots as a result of SA application.

\section{Effect of SA on GSH, GSSG and \\ PSSG levels in fruits}

In green fruits of tomato, the level of GSH was significantly higher $(\mathrm{P}<0.05)$ in treated compared to check plants (Figure 2). At lower rate of application of $\mathrm{SA}\left(5.0 \mu \mathrm{g} \mathrm{mL}^{-1}\right)$, the GSH levels were found to increase $(\mathrm{P}<0.05)$ as

Table 1. Means and least significant differences $(P=0.05)$ of the concentration distribution of GSH, GSSG and PSSG in leaf and root at predetermined intervals following application of $\mathrm{SA}$ at 5.0 and $10 \mathrm{~g} \mathrm{~mL}^{-1}$.

\begin{tabular}{|c|c|c|c|c|c|c|}
\hline \multicolumn{7}{|c|}{ Distribution of reduced, oxidized and bound glutathione } \\
\hline & $\begin{array}{l}\text { GSH mean } \\
\left(\mu \mathrm{g} \mathrm{g}^{-1}\right)\end{array}$ & $\begin{array}{c}\text { LSD } \\
(P=0.05)\end{array}$ & $\begin{array}{l}\text { Leaf } \\
\text { GSSG } \\
\text { mean } \\
\left(\mu \mathrm{g} \mathrm{g}^{-1}\right)\end{array}$ & $\begin{array}{c}\text { LSD } \\
(\mathrm{P}=0.05) \\
\left(\mu \mathrm{g} \mathrm{g}^{-1}\right)\end{array}$ & $\begin{array}{l}\text { PSSG } \\
\text { mean }\end{array}$ & $\begin{array}{c}\text { LSD } \\
(P=0.05)\end{array}$ \\
\hline \multirow{4}{*}{$\begin{array}{l}\text { Dose } \\
0.0 \mathrm{~g} \mathrm{~mL}^{-1} \\
5.0 \mathrm{~g} \mathrm{~mL}^{-1} \\
10.0 \mathrm{~g} \mathrm{~mL}^{-1}\end{array}$} & & 0.03 & & 0.02 & & 0.07 \\
\hline & $0.97^{\mathrm{a}}$ & & $0.33^{\mathrm{a}}$ & & $2.32^{\mathrm{a}}$ & \\
\hline & $1.14^{\mathrm{b}}$ & & $0.49^{\mathrm{b}}$ & & $3.33^{\mathrm{b}}$ & \\
\hline & $1.48^{\mathrm{c}}$ & & $0.60^{c}$ & & $4.51^{\mathrm{c}}$ & \\
\hline \multirow{9}{*}{$\begin{array}{l}\text { Day } \\
0 \\
15 \\
30 \\
60 \\
90 \\
120\end{array}$} & & 0.04 & & 0.03 & & 0.09 \\
\hline & $0.56^{\mathrm{a}}$ & & $0.45^{\mathrm{a}}$ & & $0.92^{\mathrm{a}}$ & \\
\hline & $3.43^{\mathrm{b}}$ & & $0.80^{\mathrm{b}}$ & & $8.10^{\mathrm{b}}$ & \\
\hline & $0.78^{c}$ & & $0.37^{c}$ & & $9.37^{c}$ & \\
\hline & $0.84^{\mathrm{d}}$ & & $0.47^{\mathrm{d}}$ & & $1.57^{\mathrm{d}}$ & \\
\hline & $0.89 \mathrm{e}$ & & $0.65^{\mathrm{e}}$ & & $0.19^{\mathrm{e}}$ & \\
\hline & $0.65^{\mathrm{f}}$ & & $0.08^{f}$ & & $0.16^{\mathrm{e}}$ & \\
\hline & & & Root & & & \\
\hline & $\begin{array}{l}\text { GSH mean } \\
\left(\mu \mathrm{g} \mathrm{g}^{-1}\right)\end{array}$ & $\begin{array}{c}\text { LSD } \\
(P=0.05)\end{array}$ & $\begin{array}{c}\text { GSSG } \\
\text { mean } \\
\left(\mu g g^{-1}\right)\end{array}$ & $\begin{array}{c}\text { LSD } \\
(\mathrm{P}=0.05) \\
\left(\mu \mathrm{g} \mathrm{g}^{-1}\right)\end{array}$ & $\begin{array}{l}\text { PSSG } \\
\text { mean }\end{array}$ & $\begin{array}{c}\text { LSD } \\
(P=0.05)\end{array}$ \\
\hline \multicolumn{2}{|l|}{ Dose } & 0.004 & & 0.002 & & 0.004 \\
\hline $0.0 \mathrm{~g} \mathrm{~mL}^{-1}$ & $0.12^{\mathrm{a}}$ & & $0.06^{\mathrm{a}}$ & & $0.09^{a}$ & \\
\hline $5.0 \mathrm{~g} \mathrm{~mL}^{-1}$ & $0.13^{\mathrm{b}}$ & & $0.07^{\mathrm{b}}$ & & $0.10^{\mathrm{b}}$ & \\
\hline $10.0 \mathrm{~g} \mathrm{~mL}^{-1}$ & $0.14^{c}$ & & $0.08^{c}$ & & $0.11^{c}$ & \\
\hline \multirow{7}{*}{$\begin{array}{l}\text { Day } \\
0 \\
15 \\
30 \\
60 \\
90 \\
120\end{array}$} & & 0.005 & & 0.003 & & 0.005 \\
\hline & $0.11^{\mathrm{a}}$ & & $0.09^{\mathrm{a}}$ & & $0.09^{\mathrm{a}}$ & \\
\hline & $0.10^{\mathrm{b}}$ & & $0.07^{\mathrm{b}}$ & & $0.10^{\mathrm{b}}$ & \\
\hline & $0.19 c$ & & $0.05^{c}$ & & $0.08^{c}$ & \\
\hline & $0.13^{\mathrm{d}}$ & & $0.05^{\mathrm{c}}$ & & $0.12^{\mathrm{d}}$ & \\
\hline & $0.14^{\mathrm{e}}$ & & $0.11^{\mathrm{d}}$ & & $0.12^{\mathrm{d}}$ & \\
\hline & $0.12^{\mathrm{f}}$ & & $0.04^{\mathrm{e}}$ & & $0.10^{\mathrm{e}}$ & \\
\hline
\end{tabular}

Dose average is the mean of 30 observations ( 5 replications $x 6$ time intervals). Day average is the mean of 15 observations ( 5 replications $x 3$ doses). ${ }^{a-1}$ Means not labeled with the same letter differ significantly at the $5 \%$ level, MANOVA test. 
the fruits matured from green ( 0.56 to $0.66 \mu \mathrm{g}$ $\left.\mathrm{g}^{-1}\right)$ to yellow (1.36 to $1.51 \mu \mathrm{g} \mathrm{g}^{-1}$ ) stage and then declined $(\mathrm{P}<0.05)$ on ripening to table red (0. 85-0.97 $\left.\mathrm{\mu g} \mathrm{g}^{-1}\right)$ stage (Table 2). At higher rate of application $\left(10.0 \mu \mathrm{g} \mathrm{mL}^{-1}\right)$, this trend was less pronounced. The data clearly indicated an increase of fruit GSH level at the lower rate of application of SA. In contrast to $\mathrm{GSH}$, the GSSG levels declined $(\mathrm{P}<0.05)$ on ripening of fruits but always remained high $(\mathrm{P}<0.05)$ in check compared to those in treated plants. The PSSG levels increased $(\mathrm{P}<0.05)$ concomitant with the decrease of GSSG level as the fruit matured from green to red (Figure 2). The decrease in GSSG level was more $(\mathrm{P}<0.05)$ in treated than check plants. The data showed that the levels of PSSG increased with decrease of GSSG in fruits. The PSSG level was similar at green and yellow stage of fruit maturation but increased $(\mathrm{P}<0.05)$ when the fruit became table red. There was an increase in GSH and PSSG levels at lower rate (5.0 $\mu \mathrm{g}$ $\mathrm{mL}^{-1}$ ) but a comparative decrease at higher rate $\left(10.0 \mu \mathrm{g} \mathrm{mL} \mathrm{m}^{-1}\right)$ of $\mathrm{SA}$ treatment.

Multivariate analysis of variance (MANOVA) revealed that PSSG was the major metabolite both in leaves and roots over a period of 120 days followed by GSH and GSSG in that order (Table 1). In leaf, a good correlation existed between GSH and GSSG ( $\left.\mathrm{r}=0.71^{* *}\right)$ and GSH and PSSG $\left(\mathrm{r}=0.54^{* *}\right)$. In root, also a good correlation existed between the levels of GSH and GSSG $\left(0.61^{* *}\right)$ and GSH and PSSG $\left(0.44^{*}\right)$. The GSH levels in leaf and root could be well correlated $\left(\mathrm{r}=0.58^{*}\right)$. The SA treatment influenced the GSH level to a greater extent than GSSG level in both leaf and root tissues and resulted in concomitant increase of PSSG in both leaf and root tissues. In fruits, GSH was the predominant metabolite followed by PSSG and GSSG in that order (Table 2).

\section{Effect of SA on redox status of crop}

The ratio of GSH/GSSG in leaf was always higher in check (1.52-8.29) compared to that in treated (1.13-7.58) plants (Figure 3). This ratio showed a similar but fluctuating trend in root due to transient increase of both GSH and GSSG levels. The ratio of GSH/GSSG reached maximum by 15 days in leaf and 30 days in root and finally peaked again by 120 days in both leaf and root. SA treatment lowered the ratio of GSH/GSSG. The effect was more in leaf than root. On the contrary, in fruits, the GSH/GSSG ratio was higher in treated than control plants. This ratio increased rapidly from green to yellow stage and then declined gradually at table ripe stage. The data showed that application of SA resulted in lowering of the ratio of GSH/GSSG during crop growth and elevation of the level by the time the fruits ripened to table red stage.

\section{Effect of SA on crop resistance to \\ $M$. incognita}

The crop resistance to $M$. incognita was estimated in terms of soil population and rootinfection. The initial $M$. incognita population measured 3.12-3.30 second-stage juveniles (J2) $\mathrm{g}^{-1}$ of soil (Table 3 ). The final population level in soil declined by 8.3 to $19.7 \%$ in SA treatments against an increase of $21.7 \%$ in control. Thus, SA adversely affected the repro- duction of the nematode. Estimation of rootgalling in tomato on a $0-5$ scale by 120 days of crop growth showed root gall index of 1.8-2.1 in SA treatments compared to a high root-gall index of 3.0 in control.

\section{Effect of SA on crop growth and yield}

In general, a stunted plant growth was discernible after the midseason approximately 60

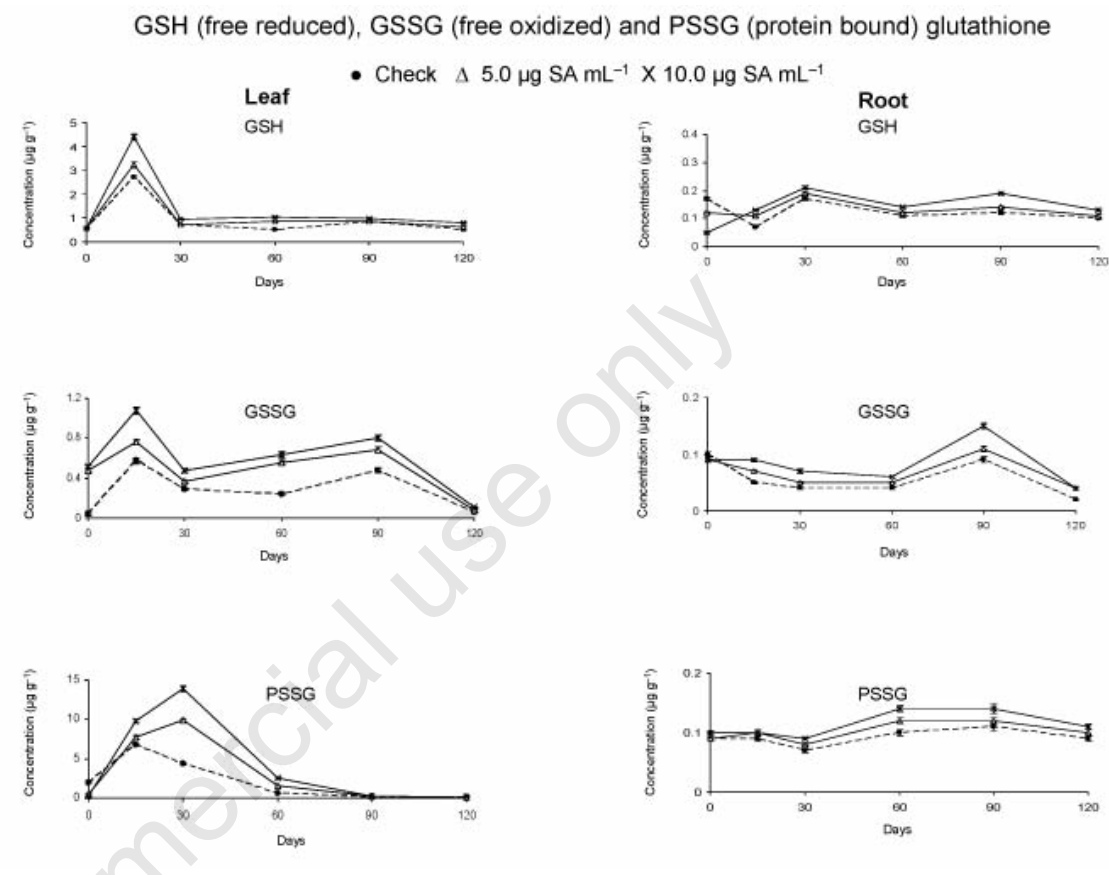

Figure 1. Free and bound glutathione in tomato crop as affected by foliar application of salicylic acid.

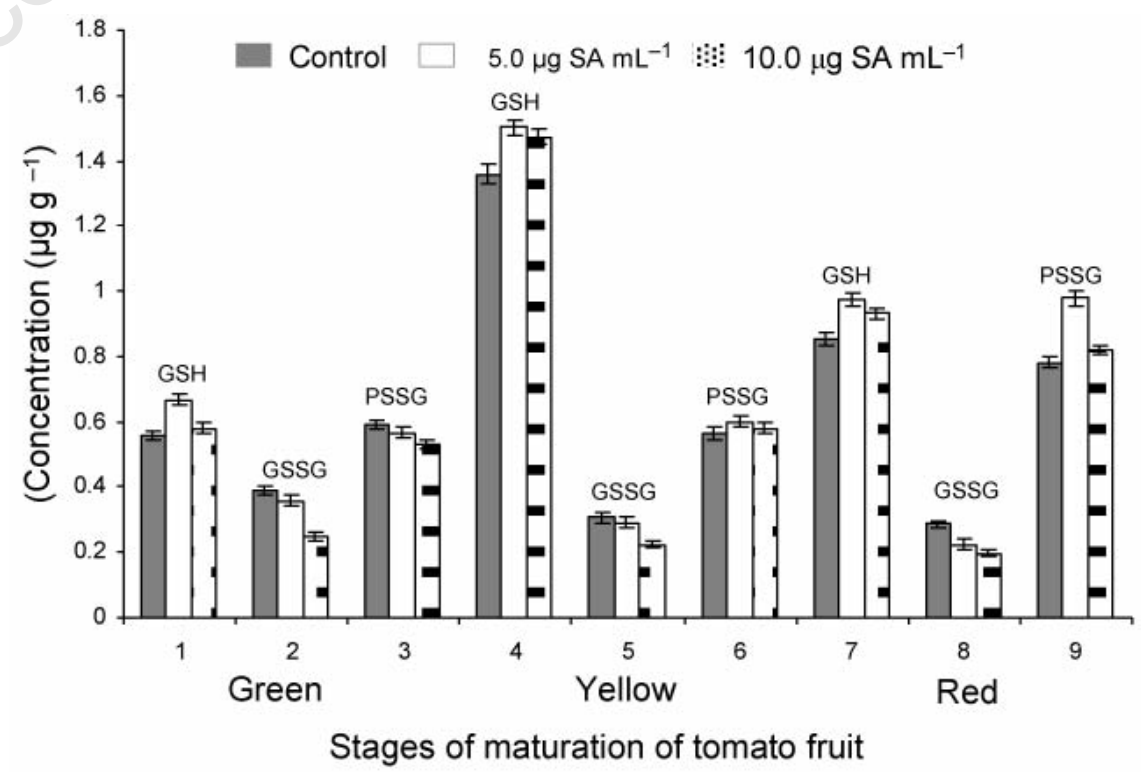

Figure 2. Free reduced (GSH), free oxidized (GSSG) and protein bound (PSSG) glutathione in tomato fruit as affected by foliar treatments of the transplants with SA (1, 2 and $3=$ green, 4,5 and $6=$ yellow, 7,8 and $9=$ red stages). 
days after application of SA. Measurement of shoot length on 120th day showed a decrease $(\mathrm{P}<0.05)$ in plant growth due to SA treatments. As compared to check, the pooled crop yield from different pickings of tomato was found to increase $(\mathrm{P}<0.05)$ at lower rate $\left(5.0 \mu \mathrm{g} \mathrm{mL} \mathrm{m}^{-1}\right)$ of application. The yield was at par $(\mathrm{P}>0.05)$ with higher rate of treatment.

\section{Discussion}

\section{Analytical method}

The chromatographic runs were easiest and quickest to perform as compared to earlier reports..$^{22,23}$ In the present investigation, BPDS was preferred over DTT as stabilizer in the extract as BPDS prevents thiol oxidation and thiol disulfide interchange and does not interfere with the quantitation of GSSG..$^{24}$ Further, a well known preservative methyl paraben was included in the extraction step to prevent oxidation of reduced metabolite species. DTT was used to reduce protein bound PSSG. ${ }^{25}$ A similar alkylation, derivatization and ethereal extraction were followed by Meher et al. ${ }^{21}$ for quantification of protein amino acids from tomato. The LOQ and LOD values were similar to the literature reports. ${ }^{22-24}$ Recoveries of GSH and GSSG from the test plant tissues were similar to those of $86-98 \%$ from wheat ${ }^{23,25}$ and 71.6 $100.3 \%$ from woody plant tissues..$^{22}$ The results showed that this method is precise, sensitive, and reproducible, providing a rapid and useful quantitative tool for the analysis of GSH and GSSG from tomato. The recoveries of the analytes being satisfactory, no correction factor were used in the final calculations of their concentrations.

\section{Changes in glutathione status}

Higher levels of GSH and GSSG in leaf and fruit than root are expected since GSH and GSSG are components of the chloroplast antioxidant system ${ }^{26}$ and root depends on shoot for transfer of GSH via the phloem. ${ }^{27}$ In the present investigations, a higher concentration of GSH compared to GSSG and high level of protein bound glutathione was evinced throughout the period of tomato crop growth. The increase in root GSH was ascribed to basipetal translocation from shoot to root. The observed values of GSH, GSSG and PSSG in root, leaf and fruits were well within the limits and in accordance with the literature values. For example, the content of GSH in plant tissue has been reported to range from 0.1-3 mM with a low concentration of GSSG. ${ }^{22}$ Brussels sprouts contained $1.12 \mu \mathrm{M} \mathrm{GSH} \mathrm{g}^{-1}$ fresh weights. ${ }^{28}$ In wheat, the GSH level ranged from $18-89 \mathrm{nmol} \mathrm{g}^{-1}$ flour, GSSG 12-22 $\mathrm{nmol} \mathrm{g}^{-1}$ flour and PSSG 70-150 nmol g ${ }^{-1}$ flour. $^{25} \mathrm{GSH}$ always represented a high percentage of total glutathione, with highest levels $\left(73 \mathrm{nmol} \mathrm{g}{ }^{-1}\right.$ dry wt) in leaves and lowest ( $25 \mathrm{nmol} \mathrm{g}^{-1}$ dry wt) in roots of peach plant. ${ }^{22}$ Seeds of cherry and sugar pine contained high levels of GSH, 403 and $401 \mathrm{nmol} \mathrm{g}^{-1}$ dry wt, respectively. ${ }^{22}$

The observed changes in antioxidant levels following application of SA could be due to oxidative stress caused by reactive oxygen species (ROS) generated in glutathione perox-

Table 2. Means and least significant differences (LSD) $(P=0.05)$ of the concentration distribution GSH, GSSG and PSSG in tomato fruit at three different stages of maturation following application of $\mathrm{SA}$ at 5.0 and $10 \mathrm{~g} \mathrm{~mL}^{-1}$.

\begin{tabular}{|c|c|c|c|c|c|c|}
\hline \multicolumn{7}{|c|}{ Distribution of reduced, oxidized and bound glutathione } \\
\hline & $\begin{array}{l}\text { GSH mean } \\
\left(\mu \mathrm{g} \mathrm{g}^{-1}\right)\end{array}$ & $\begin{array}{c}\text { LSD } \\
(\mathrm{P}=0.05)\end{array}$ & $\begin{array}{c}\text { Leaf } \\
\text { GSSG } \\
\text { mean } \\
\left(\mu \mathrm{g} \mathrm{g}^{-1}\right)\end{array}$ & $\begin{array}{c}\text { LSD } \\
(\mathrm{P}=0.05) \\
\left(\mu \mathrm{g} \mathrm{g}^{-1}\right)\end{array}$ & $\begin{array}{l}\text { PSSG } \\
\text { mean }\end{array}$ & $\begin{array}{c}\text { LSD } \\
(P=0.05)\end{array}$ \\
\hline $\begin{array}{l}\text { Dose } \\
0.0 \mu \mathrm{g} \mathrm{mL}-1 \\
5.0 \mu \mathrm{mL}^{-1} \\
10.0 \mu \mathrm{g} \mathrm{mL}^{-1}\end{array}$ & $\begin{array}{l}0.92^{\mathrm{a}} \\
1.05^{\mathrm{b}} \\
1.00^{\mathrm{c}}\end{array}$ & 0.039 & $\begin{array}{l}0.33^{\mathrm{a}} \\
0.29^{\mathrm{b}} \\
0.22^{\mathrm{c}}\end{array}$ & 0.025 & $\begin{array}{l}0.65^{\mathrm{a}} \\
0.71^{\mathrm{b}} \\
0.64^{\mathrm{c}}\end{array}$ & 0.033 \\
\hline $\begin{array}{l}\text { Stage } \\
\text { green } \\
\text { yellow } \\
\text { red }\end{array}$ & $\begin{array}{l}0.60^{\mathrm{a}} \\
1.45^{\mathrm{b}} \\
0.92^{\mathrm{c}}\end{array}$ & 0.039 & $\begin{array}{l}0.33^{\mathrm{a}} \\
0.27^{\mathrm{b}} \\
0.24^{\mathrm{c}}\end{array}$ & 0.025 & $\begin{array}{l}0.58^{\mathrm{a}} \\
0.61^{\mathrm{b}} \\
0.86^{\mathrm{c}}\end{array}$ & 0.033 \\
\hline
\end{tabular}

Dose average is the mean of 15 observations ( 5 replications $x 3$ stages of fruit maturation). Stage average is the mean of 15 observations ( 5 replications x 3 doses). a-cMeans not labeled with the same letter differ significantly at the 5\% level, MANOVA test.

Table 3. Effect of foliar application of SA on plant resistance against root-knot nematode $M$. incognita, root-galling, plant growth and yield of tomato (average of five replications).

\begin{tabular}{|c|c|c|c|c|c|c|}
\hline Treatment & $\begin{array}{c}\mathrm{N} \\
\mathrm{pc} \\
\text { Initial } \\
\text { (Pi) }\end{array}$ & $\begin{array}{l}\text { e } \\
\text { Final* } \\
\text { (Pf) }\end{array}$ & $\begin{array}{c}\text { Reproduction } \\
\text { factor } \\
\text { Pf/Pi }\end{array}$ & $\begin{array}{l}\text { Gall } \\
\text { index }\end{array}$ & $\begin{array}{l}\text { Shoot } \\
\text { length** } \\
\text { (cm) }\end{array}$ & $\begin{array}{l}\text { Yield*** } \\
\text { (tons/ha) }\end{array}$ \\
\hline 0 & $\begin{array}{c}3.27 \\
(0.101)\end{array}$ & $\begin{array}{c}3.98^{\mathrm{a}} \\
(0.097)\end{array}$ & $\begin{array}{c}1.22 \\
(0.134)\end{array}$ & 3.0 & $\begin{array}{c}65.9^{\mathrm{a}} \\
(1.313)\end{array}$ & $\begin{array}{l}11.20^{\mathrm{a}} \\
(0.282)\end{array}$ \\
\hline 1 & $\begin{array}{c}3.11 \\
(0.116)\end{array}$ & $\begin{array}{c}2.86 \mathrm{~b} \\
(0.114)\end{array}$ & $\begin{array}{c}0.92 \\
(0.099)\end{array}$ & 2.1 & $\begin{array}{c}62.5^{\mathrm{b}} \\
(1.151)\end{array}$ & $\begin{array}{c}12.46^{\mathrm{b}} \\
(0.306)\end{array}$ \\
\hline 2 & $\begin{array}{c}3.38 \\
(0.107)\end{array}$ & $\begin{array}{c}2.65^{\mathrm{c}} \\
(0.103)\end{array}$ & $\begin{array}{c}0.78 \\
(0.076)\end{array}$ & 1.8 & $\begin{array}{c}60.8 \mathrm{~b} \\
(1.244)\end{array}$ & $\begin{array}{c}12.59^{\mathrm{b}} \\
(0.298)\end{array}$ \\
\hline
\end{tabular}

Treatment $0=$ check, $1=5.0$ and $2=10.0 \mu \mathrm{g} \mathrm{mL}^{-1} \mathrm{SA}$. Figures in parentheses are values of the standard errors of mean. LSD $(\mathrm{P}=0.05) * 0.18$, $* * 2.46$ and ${ }^{* * *} 0.59$. a-c-Means not labeled with the same letter differ significantly at the $5 \%$ level, MANOVA test.

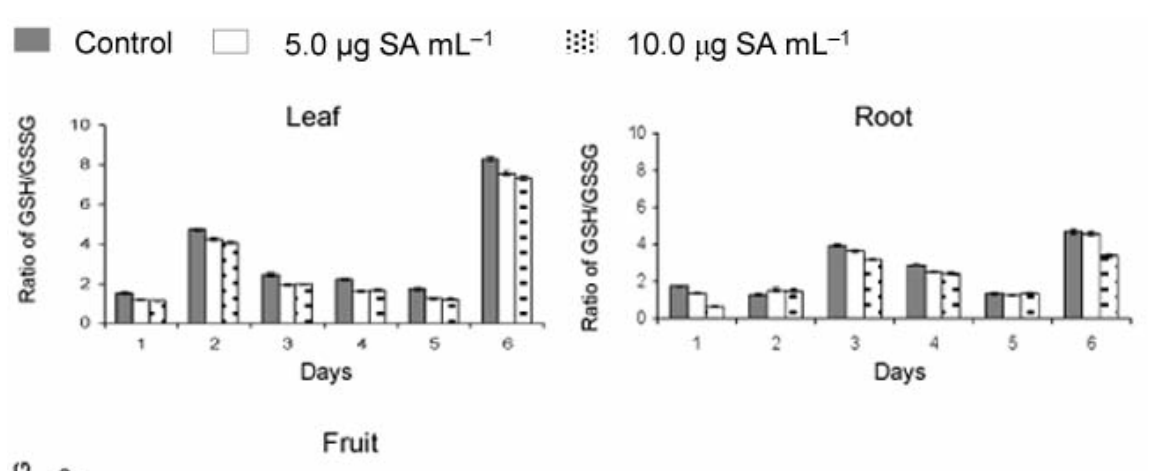

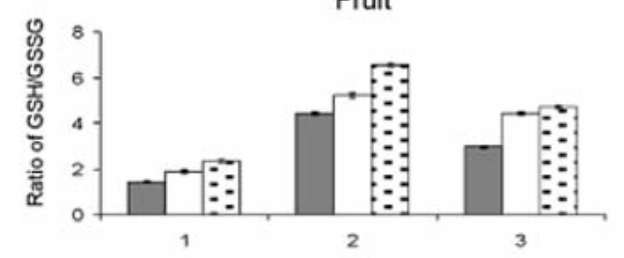

Stages of maturation of tomato fruit
Figure 3. Effect of salicylic acid (SA) on redox status of tomato during crop growth and fruit maturation (days $1=0,2=15,3=30,4=60,5$ $=90$ and $6=120$ days after application; stage 1 = green, 2 = yellow and 3 $=$ red fruits). 
idase (GPX) catalyzed reaction, ${ }^{29}$ surpassing detoxification of SA by glutathione transferase (GST). ${ }^{30}$ This probably induced closure of stomata and caused dehydroascorbic acid dehydrogenase to use GSH as electron donor for reduction of DHA to produce ascorbate and GSSG. ${ }^{31}$ The observed increases in GSSG were further utilized by glutathione reductase GR/thioredoxin-Trx (red) to reduce GSSG to GSH for maintaining a high ratio of GSH/GSSG. With the lowering of ROS, the oxidative stress could have induced transcription of antioxidant genes including $\gamma$-glutamylcysteine synthetase (GSH1). ${ }^{10}$ GSH1 and to a lesser extent glutathione synthetase (GSH2) expression has been reported to be strongly up regulated for an upgraded GSH synthesis ${ }^{10}$ crucial for the cellular adaptation to oxidative stress. ${ }^{32}$ Regulation of the expression of active GSH1 enzyme at transcriptional, translational and post-transnational levels has been reported. ${ }^{33,34}$ The increase in levels of PSSG in the present studies in response to SA application could be the resultant of glutathionylated proteins formed during oxidative stress for cellular antioxidant defense. ${ }^{35}$

\section{Redox status}

The ratio of GSH/GSSG was lower than the normal 7 beyond 90 days of SA application amidst changes in concentrations of GSH and GSSG. This could be due to adverse effect of SA on the expression of GSH1/activity of GR. ${ }^{27,36,37}$ The GSH1 expression has been reported to be modulated by stress hormone jasmonic acid (JA). ${ }^{9}$ SA has been shown to antagonize JAmediated responses. ${ }^{3,38}$ Integration of SA and JA signaling has been demonstrated ${ }^{39}$ and SA reported to increase de novo biosynthesis of $\mathrm{GSH} .{ }^{40}$ In our studies, the ratio of GSH/GSSG was observed to be more in leaf and fruit than root tissues. In parallel with our observations, imbalances in GHS/GSSG ratio were reported when plants were exposed to oxidative stress. ${ }^{22}$ Siller-Cepeda et al..$^{22}$ measured a GSH/GSSG ratio of 1.2 in leaf and 0.5 in root of peach and 6.5 in cherry seeds and 4.2 in sugar pine seeds. In contrast to highest GSH concentrations observed in yellow fruit, GSH concentrations were reported to be more in dark-green exocarps, with lower enzyme activities than lightgreen exocarp. ${ }^{41}$ The decline in free GSH level on maturity of fruit from yellow to red stage could be due to utilization of GSSG in the formation of bound glutathione $\mathrm{e}^{35}$ and to a lesser extent to the decreased activity of GR, the enzyme responsible for reduction of GSSG to GSH.

\section{Crop resistance}

The reduction of root infection by $M$. incognita exhibiting a lower root gall index and the resultant reduction in soil population in treat- ments as compared to check could be due to both SA-induced $\mathrm{SAR}^{3,38}$ and sulfur-induced defense by elemental sulfur $\left(\mathrm{S}^{0}\right)$ produced from glutathione transported from shoot to root, its distribution and degradation. ${ }^{42}$ Accumulation of $\mathrm{S}^{0}$ and thiols in tomato has been reported to act against vascular fungal pathogen ${ }^{42}$ and enhanced glutathione metabolism correlated with sulfur-induced resistance in tobacco mosaic virus-infected susceptible Nicotiana tabacum plants. $^{43}$ Our study clearly demonstrated prolonged activation of glutathione metabolism by SA during the entire cropping season. Long-lasting chemical changes in the plant, from days to weeks and even years, despite transient induced defense responses, have been reported. ${ }^{44}$

\section{Crop growth and yield}

The stunted plant growth probably resulted from the imbalances in the ratio of GSH/GSSG which could have affected cell division, cellular differentiation, growth regulation and stress signaling $^{1}$ as well as root meristem activity. ${ }^{45}$ SA has been associated with reduced plant growth and decreased plant fitness. ${ }^{46}$ The yield increase despite reduced plant growth, could be due to long lasting resistance response against $M$. incognita and elevated GSH biosynthesis causing early flowering. ${ }^{47}$ Earlier, SA has been reported to induce transition from vegetative to reproductive growth, its accumulation related to flowering. ${ }^{48,49}$ Our data showed that SA enhanced GSH level in leaf during crop growth and fruit maturation. Apparently, SA stimulated GSH biosynthesis to induce early flowering culminating in increased yield. The GSH level correlated with early flowering has been ascribed to light intensity and photosynthesis ${ }^{47}$ and plant fitness after pathogen resistance to environmental conditions..$^{50}$

The present study firstly indicated a link between SA and activation of glutathione metabolism during a compatible plant-nematode interaction to cause sulfur-induced resistance besides SA-induced defense enhancing yield and functional food quality of tomato in terms of elevated GSH level in fruit.

\section{Conclusions}

From the present study, it can be concluded that SA activated glutathione metabolism, augmented glutathione status of crop, imparted resistance against Meloidogyne incognita and improved yield and fruit quality. The study provided additional insight to SA-induced resistance mechanism against obligate phytopathogen and indirectly assigned a number of enzyme functions. SA can be applied at 5.0 $\mu \mathrm{g} \mathrm{mL} \mathrm{m}^{-1}$ as xenobiotics to foliage for metabolic engineering of tomato at transplanting to derive pathogen resistance and functional food quality while formulating nematode management strategy.

\section{References}

1. Noctor G, Foyer CH. Ascorbate and glutathione: keeping active oxygen under control. Annu Rev Plant Physiol Plant Mol Biol 1998;49:249-79.

2. Foyer $\mathrm{CH}$, Noctor G. Redox regulation and photosynthetic organisms: signaling, acclimation, and practical implications. Antiox Redox Sign 2009;11:861-905.

3. Bostock RM. Signal crosstalk and induced resistance: straddling the line between cost and benefit. Annu Rev Phytopathol 2005;43:545-80.

4. Heil M, Ton J. Long-distance signalling in plant defence. Trends Plant Sci 2008;13:264-72.

5. Pieterse CMJ, Leon-Reyes A, Van der Ent S, Van Wees SC. Networking by small-molecule hormones in plant immunity. Nat Chem Biol 2009;5:308-16.

6. Molinari S, Baser N. Induction of resistance to root-knot nematodes by SAR elicitors in tomato. Crop Protec 2010;29:1354-62.

7. Tan X, Meyers BC, Kozik A, West MA, Morgante M, St Clair DA, et al. Global expression analysis of nucleotide binding site-leucine rich repeat-encoding and related genes in Arabidopsis. BMC Plant Biol 2007;7:56.

8. Ishikawa T, Shigeoka S. Recent advances in ascorbate biosynthesis and the physiological significance of ascorbate peroxidase in photosynthesizing organisms. Biosci Biotechnol Biochem 2008;72:1143-54.

9. Pastori GM, Kiddle G, Antoniw J, Bernard S, Veljovic-Jovanovic S, Verrier PJ, et al. Leaf vitamin $\mathrm{C}$ contents modulate plant defense transcripts and regulate genes that control development through hormone signaling. Plant Cell 2003;15:939-51.

10. Wachter A, Rausch T. Regulation of glutathione (GSH) synthesis in plants: Novel insight from Arabidopsis. FAL Agric Res 2005;283:149-55.

11. Meher HC, Koundal KR, Gajbhiye VT. Reactive oxygen species, antioxidants, sulfur metabolites and their agro-biotechnological potential to enhance stress resistance of crop plants. Indian J Agric Biochem 2010;23:1-17.

12. Shi Q, Zhu Z. Effects of exogenous salicylic acid on manganese toxicity, element contents and antioxidative system in cucumber. Environ Exp Bot 2008;63:317-26.

13. Mills BJ, Stinson CT, Liu MC, Lang CA. Glutathione and cyst(e)ine profiles of veg- 
etables using high performance liquid chromatography with dual electrochemical detection. J Food Comp Anal 1997;10:90-1.

14. Silber R, Farber CM, Papadopoulos E, Nervla D, Liebes L, Bruck M, et al. Glutathione depletion in chronic lymphocytic leukemia B lymphocytes. Blood 1992;80:2038-43.

15. Kumar A, Sharma S, Pundir CS, Sharma A. Decreased plasma glutathione in cancer of the uterine cervix. Cancer Lett 1995;94:10711.

16. Cantin AM, Hubbard RC, Crystal RG. Glutathione deficiency in the epithelial lining fluid of the lower respiratory tract in idiopathic pulmonary fibrosis. Am Rev Respir Dis 1989;139:370-2.

17. Pacht ER, Timemam AP, Lykens MG, Merola AJ. Deficiency of alveolar fluid glutathione in patients with sepsis and the adult respiratory distress syndrome. Chest 1991;100:1397-403.

18. de Quay B, Malinverni R, Lauterburg BH. Glutathione depletion in HIV-infected patients: role of cysteine deficiency and effect of oral $\mathrm{N}$-acetylcysteine. AIDS 1992;6:815-19.

19. Sasser JN, Freckman DW. A world perspective on nematology: the role of the Society. In: Veech JA, Dickson DW, eds. Vistas on Nematology. Hyattsville, MD: Society of Nematologists; 1978. pp. 7-14.

20. Taylor AL, Sasser JN. Biology, Identification and Control of Root-knot Nematodes (Meloidogyne Species). Raleigh, NC: North Carolina State University Graphics; 1978.

21. Meher HC, Gajbhiye VT, Singh G. A GC-ECD method for estimation of free and bound amino acids, $\gamma$-aminobutyric acid, salicylic acid and acetyl salicylic acid from Solanum lycopersicum (L.). J AOAC Int 2011;93:232 42.

22. Siller-Cepeda JH, Chen THH, Fuchigami LH. High performance liquid chromatography analysis of reduced and oxidized glutathione in woody plant tissues. Plant Cell Physiol 1991;32:1179-85.

23. Schofield JD, Chen X. Analysis of free reduced and free oxidized glutathione in wheat flour. J Cereal Sci 1995;21:127-36.

24. Fariss MW, Reed DJ. High-performance liquid chromatography of thiols and disulfides: Dinitrophenol derivatives. Methods Enzymol 1987;143:101-9.

25. Chen X, Schofield JD. Determination of protein-glutathione mixed disulfides in wheat flour. J Agric Food Chem 1995;43:2362-68.

26. Alscher RG. Biosynthesis and antioxidant function of glutathione in plants. Physiol Plant 1989;77:457-64.

27. Rennenberg H, Molecular approaches to glutathione biosynthesis. In: Cram WJ, De Kok LJ, Brunold C, Rennenberg H, eds.
Sulfur Metabolism in Higher Plants: Molecular, Ecophysiological and Nutritional Aspects. Leiden: Backhuys Publishers; 1997. pp. 59-70.

28. Guo CJ, Cao G, Sofic E, Prior RL. High-performance liquid chromatography coupled with coulometric array detection of electroactive components in fruits and vegetables: relationship to oxygen radical absorbance capacity. J Agric Food Chem 1997;45:1787-96.

29. Chae HZ, Kang SW, Rhee SG. Isoforms of mammalian peroxiredoxin that reduce peroxides in presence of thioredoxin. Methods Enzymol 1999;300:219-26.

30. Wagner U, Edwards R, Dixon DP and Mauch F, Probing the diversity of the Arabidopsis glutathione S-transferase gene family. Plant Mol Biol 2002;49:515-32.

31. Chen Z and Gallie DR, The ascorbic acid redox state controls guard cell signaling and stomatal movement. Plant Cell 2004;16:1143-62.

32. Carmel-Harel 0, Stearman R, Gasch AP, Botstein D, Brown P0, Storz G. Role of thioredoxin reductase in the Yaplpdependent response to oxidative stress in Saccharomyces cerevisiae. Mol Microbiol 2001;39:595-605.

33. Wachter A, Wolf S, Steininger H, Bogs J, Rausch T. Differential targeting of GSH1 and GSH2 is achieved by multiple transcription initiation: Implications for the compartmentation of glutathione biosynthesis in the Brassicaceae. Plant J 2005;41:15-30.

34. Jez JM, Cahoon RE, Chen S. Arabidopsis thaliana glutamate-cysteine ligase: functional properties, kinetic mechanism, and regulation of activity. $\mathrm{J}$ Biol Chem 2004;279:33463-70.

35. Holmgren A. Antioxidant functions of thioredoxin and glutaredoxin systems. Antioxid Redox Signal 2000;2:811-20.

36. Foyer AH, Noctor G. The molecular biology and metabolism of glutathione: Significance of Glutathione to Plant Adaptation to the Environment (ed.) by Grill D, Tausz M and De Kok LJ. Dordrecht: Kluwer Academic Publishers; 2001. pp. 2756.

37. Zhu YL, Pilon-Smits EA, Tarun AS, Weber SU, Jouanin L, Terry N. Cadmium tolerance and accumulation in Indian mustard is enhanced by overexpressing $\gamma$-glutamylcysteine synthetase. Plant Physiol 1999;121:1169-78.

38. Zarate SI, Kempema LA, Walling LL. Silverleaf whitefly induces salicylic acid defenses and suppresses effectual jasmonic acid defenses. Plant Physiol 2007;143:866-75.

39. Li J, Brader G, Palva ET. The WRKY70 transcription factor: A node of convergence for jasmonate-mediated and salicylate-mediat- ed signals in plant defense. Plant Cell 2004;16:319-31.

40. Yoshida S, Tamaoki M, Ioki M, Ogawa D, Sato Y, Aono M, et al. Ethylene and salicylic acid control glutathione biosynthesis in ozone-exposed Arabidopsis thaliana. Physiol Plant 2009;136:284-98.

41. Torres CA, Andrews PK. Developmental changes in antioxidant metabolites, enzymes, and pigments in fruit exocarp of four tomato (Lycopersicon esculentum Mill.) genotypes: beta-carotene, high pigment-1, ripening inhibitor, and 'Rutgers'. Plant Physiol Biochem 2006;44:806-18.

42. Williams JS, Hall SA, Hawkesford MJ, Beale MH, Cooper RM. Elemental sulfur and thiol accumulation in tomato and defense against a fungal vascular pathogen. Plant Physiol 2002;128:150-9.

43. Höller K, Király L, Künstler A, Müller M, Gullner G, Fattinger M, et al. Enhanced glutathione metabolism is correlated with sulfur-induced resistance in Tobacco mosaic virus-infected genetically susceptible Nicotiana tabacum plants. Mol Plant Microbe Interact 2010;23:1448-59.

44. Agrawal AA, Tuzun S, Bent, E, eds. Induced plant defenses against pathogens and herbivores. St. Paul: APS Press; 1999.

45. Vernoux T, Wilson RC, Seeley KA, Reichheld JP, Muroy S, Brown S, et al. The root meristemless1/cadmium sensitive2 gene defines a glutathione-dependent pathway involved in initiation and maintenance of cell division during postembryonic root development. Plant Cell 2000;12:97-110.

46. Heil M, Baldwin IT. Fitness costs of induced resistance: emerging experimental support for a slippery concept. Trends Plant Sci 2002;7:61-7.

47. Ogawa K, Hatano-Iwasaki A, Yanagida M, Iwabuchi M. Level of glutathione is regulated by ATP dependent ligation of glutamate and cysteine through photosynthesis in Arabidopsis thaliana: mechanism of strong interaction of light intensity with flowering. Plant Cell Physiol 2004;45:1-8.

48. Jin JB, Jin YH, Lee J, Miura K, Yoo CY, Kim WY, et al. The SUMO E3 ligase, AtSIZ1, regulates flowering by controlling a salicylic acid-mediated floral promotion pathway and through it affects on FLC chromatin structure. Plant J 2008;53:530-40.

49. Martínez C, Pons E, Prats G, Leon J. Salicylic acid regulates flowering time and links defense responses and reproductive development. Plant J 2004;37:209-17.

50. Dietrich R, Ploss K, Heil M. Growth responses and fitness costs after induction of pathogen resistance depend on environmental conditions. Plant Cell Envir 2005;28: 211-22. 